\title{
MICROPLASTICITY OF 15Kh2NMFA VESSEL STEEL IN A STRESS-STRAIN STATE DURING MAGNETIC TREATMENT
}

\author{
N.A. Chernyak, V.I. Sokolenko \\ National Science Center “Kharkov Institute of Physics and Technology”, Kharkiv, Ukraine \\ E-mail: vsokol@kipt.kharkov.ua
}

\begin{abstract}
Earlier it was found that the treatment of pre-strained ferrite-pearlite vessel steel 15Kh2NMFA, welded joints of this steel by alternating magnetic field of industrial frequency leads to a decrease in the level and alignment of the stress field's relief and significantly improves the complex of physical and mechanical properties. When nonstationary magnetic fields are applied to a structurally inhomogeneous ferromagnetic material, several different mechanisms of rearrangement of the domain and defect structure can act. In this work, we propose a model of dislocation system response of ferromagnetic in a stress-strain state to a magnetic effect, based on the microscopic properties of dislocations in a mechanically unstable state.
\end{abstract}

PACS: 83.85.St;61.82.Bg; 62.40.+i

\section{INTRODUCTION}

During the manufacture and operation of products from structural materials, various sources of internal stresses arise. The existence of the latter precedes the plastic deformation onset at low values of the load, facilitates fatigue and corrosion destruction, and accelerates the degradation of operational characteristics.

Known methods for eliminating the effects caused by residual stresses include special heat treatment, highfrequency, pulsed or vibration exposure. Earlier, based on the results obtained in the study of the magnetoplastic effect, a magnetic treatment method (MT) was proposed for processing magnetically ordered metals and alloys in a stress-strain state with an alternating $(50 \mathrm{~Hz})$ magnetic field $(\mathrm{MF})$ to reduce the level and smooth out internal stresses [1,2].

The established optimal amplitude-time mode of the MT provides the effect of maximum change in the structure-sensitive properties. It was shown that as a result of MT for samples of the vessel steel, predeformed to a high degree, and welded joints of this steel, a drop in internal stresses level is realized. A more uniform distribution of these stresses, a magnetic texture appeared and a significant improvement in the complex of mechanical properties are established [3-8]. Note that when a pulsed magnetic field is used, the internal stresses level the deformed $30 \mathrm{CrMnSi}$ steel samples also decreases [9].

The nonequilibrium kinetics of the electron-phonon subsystem in ferromagnetic material having inhomogeneous defect structures as the basis of the magneto-plastic effect was considered in review [10]. When an alternating MF is applied and magnetostrictive oscillations propagate in a structurally inhomogeneous and nonequilibrium medium, several different rearrangement mechanisms of domain structure and structural state associated with a change in the mobility of crystal structure defects can act simultaneously.

This work is devoted to the creation of a model for the transformation in a stress-strain state of 15Kh2NMFA steel during MT, based on the dynamic properties of dislocations with excess linear energy.

\section{STRUCTURE TRANSFORMATION MODEL DURING MT}

From the available experimental data, it follows that the efficiency of magnetic action is most pronounced in the areas of structure inhomogeneity and internal stresses concentration [3-8]. The non-equilibrium existing in the material is the most important factor providing the sensitivity of the defect structure to MT. In high stresses field, $\sigma$, the dislocation is in a mechanically unstable state. In this case, its segment, fixed at the points $x=0, x=l$, under the action of a force per unit length, $b \sigma(b-$ Burgers vector) bends like a stretched string relative to its equilibrium position along the $\mathrm{O}_{x}$ axis. We will assume that at the initial moment of time, $t=0$, the segment had the parabola shape:

$$
y(x, 0)=4 h x(l-x) / l^{2}
$$

symmetric with respect to the perpendicular $h$ drawn through the point $x=l / 2$. With a balance between the force $b \sigma$ and the linear tension $T$, the curvature of the segment is determined by the ratio $R=T / b \sigma$. For small displacements of the dislocation line, the value $h \sim l^{2} / 8 R$ and formula (1) takes the form:

$$
y(x, 0)=b o x(l-x) / 2 T .
$$

It is known that the critical value is $R \sim l / 2$. With a further increase in $R$, a closed dislocation loop can arise, i.e., to begin work of a Frank-Read source of length $l$ [11]. According to the given relations, the critical value of the quantity $h \sim 1 / 4$.

To interpret structural rearrangements, let us estimate the limiting magnetostrictive stresses $\sigma_{M} \sim \lambda_{\mathrm{s}} E$, where $\lambda_{\mathrm{s}}$ is the saturation magnetostriction and $E$ is the elastic modulus of steel. We obtain the value of $\sigma_{M} \sim 5 \mathrm{MPa}$, which be $0.15 \sigma_{02}$, where $\sigma_{02}$ is the experimentally determined value of the yield strength of steel caused by severe deformation [6].

The conditions for significant instability of dislocation position are favorable for structural changes under the influence of a small energy impact. In the analysis, we will use the fact that in a ferromagnet the 
deformation near a dislocation can be calculated in the same way as in a nonmagnetic metal. We consider a dislocation motion under the action of a periodic force in common string model. The transverse displacement of the points of the segment $y(x, t)$ with linear tension, $T$, effective mass per unit length, $M$, when a periodic force is applied, satisfies the equation:

$$
\frac{\partial^{2} y}{\partial t^{2}}+2 \chi \frac{\partial y}{\partial t}-a^{2} \frac{\partial^{2} y}{\partial x^{2}}=p \cos \omega t .
$$

Here $a^{2}=T / M ; \chi=B / 2 M ; p=b \sigma_{M} / M ; B$ - damping constant, depending on the nature of the dissipative forces. Equation (3) with boundary conditions $y(0, t)=y \quad(1, t)=0$ and initial conditions $y(x, 0)=$ $b \sigma x(l-x) / 2 T$, assuming that the initial velocity $\dot{y}(x, 0)=0$, we solve by the method of variables separation. The solution is expressed as a series:

$$
\begin{aligned}
& y(x, t)=\sum_{n=1}^{\infty}\left[B_{2 n+1}^{(1)} \cos \left(\omega t-\delta_{2 n+1}\right)\right] \sin \frac{(2 n+1) \pi x}{l}+ \\
& +e^{-\chi t} \sum_{n=1}^{\infty}\left[B_{2 n+1}^{(2)} \cos \left(\omega_{2 n+1}^{2}-\chi^{2}\right)^{1 / 2} t+\right. \\
& \left.+B_{2 n+1}^{(3)} \sin \left(\omega_{2 n+1}^{2}-\chi^{2}\right)^{1 / 2}\right] \sin \frac{(2 n+1) \pi x}{l},
\end{aligned}
$$

where the coefficients are determined by the formulas:

$$
\begin{aligned}
& B_{2 n+1}^{(1)}=4 b \sigma M / \pi(2 n+1) M\left[\left(\omega_{2 n+1}^{2}-\omega^{2}\right)^{2}+\right. \\
& \left.+4 \chi^{2} \omega^{2}\right]^{1 / 2}, \\
& \quad B_{2 n+1}^{(2)}=4 b \sigma l^{2} / \pi^{3} T(2 n+1)^{3}, \\
& B_{2 n+1}^{(3)}=4 \chi b \sigma l^{2} / \pi^{3} T\left(\omega_{2 n+1}^{2}-\chi^{2}\right)^{1 / 2}(2 n+1)^{3}
\end{aligned}
$$

and

$$
\omega_{2 n+1}=\frac{(2 n+1) \pi a}{l}, \tan \delta_{2 n+1}=\frac{2 \chi \omega}{\omega_{2 n+1}^{2}-\omega^{2}} .
$$

For definiteness, the second term of expression (4) is written out for the case: $\chi^{2}-\omega_{2 n+1}^{2}<0$. In accordance with the well-known concepts, we will accept a simplifying assumption that the dynamic state of a segment is specified by the first members of the series $[12,13]$. Then expression (4) takes the form:

$$
\begin{aligned}
& y(x, t)=4 b_{\sigma_{M}} l^{2} \cos \left(\omega t-\delta_{0}\right) \sin \frac{\pi x}{l} / \\
& \pi^{3} T\left[\left(1-\left(\frac{\omega}{\omega_{0}}\right)^{2}\right)^{2}+\frac{4 \chi^{2} \omega^{2}}{\omega_{0}^{4}}\right]^{1 / 2}+ \\
& +e^{-\chi t}\left[\frac{4 b \sigma l^{2}}{\pi^{3} T} \cos \left(\omega_{0}^{2}-\chi^{2}\right)^{1 / 2} t+\right. \\
& \left.+\frac{\chi 4 b \sigma l^{2} \sin \left(\omega_{0}^{2}-\chi^{2}\right)^{1 / 2} t}{\pi^{3} T\left(\omega_{0}^{2}-\chi^{2}\right)^{1 / 2}}\right] \sin \frac{\pi x}{l} .
\end{aligned}
$$

The frequency of the alternating magnetic field is $\omega<<\omega_{0}$. Using this condition instead of (9), we obtain:

$$
y(x, t) \approx \frac{4 b l^{2}}{\pi^{3} T}\left[\sigma_{M} \cos \omega t+\sigma e^{-\chi t} \cos \omega_{0} t\right] \sin \frac{\pi x}{l} .
$$

The expression (10) additionally increases by $\Delta_{1} \sim \sigma_{M}$, when during one period $2 \pi / \omega_{0}$ the amplitude of the damped oscillations almost does not change, then at the time the second term reaches its maximum value. At this moment the angle of the tangent inclination to the $\mathrm{O}_{\mathrm{x}}$ axis is incremented.

$$
\left(\frac{\partial y}{\partial x}\right)_{0}=\frac{4 b l}{\pi^{2} T}\left(\sigma_{M} \cos \omega t+\sigma e^{-\chi t} \cos \omega_{0} t\right) .
$$

In microvolumes with a high level of stresses close to the yield strength when dislocation segments are vibration during the MT, it is possible to achieve critical values of $h_{\mathrm{k}}$ and the conditions for depinning of dislocations. As a result, due to the microscopic properties of dislocations, there is a combination of generation dislocations, what was mentioned above, and dislocation depinning. The dominant factor is depinning and redistribution of dislocations.

The system of oscillating dislocation segments falling into the zone of a high level of internal stresses $\sigma$ dissipates energy and undergoes dynamic braking and gradually approaches a more equilibrium state. Ultimately, a forced oscillation mode is established. The efficiency of the process decreases asymptotically $(\mathrm{t} \rightarrow \infty)$

At $\chi^{2}-\omega_{2 n+1}^{2}>0$, an abrupt establishment of such regime will take place. As in the previous case, the outflow of energy to elementary excitations (phonons, magnons) is insignificant.

At, there will be an abrupt establishment of such a regime. As in the previous case, the outflow of energy to elementary excitations (phonons, magnons) is insignificant. It follows from the above analysis that several different relaxation mechanisms with their own relaxation times, depending on the structure and state of the medium, can act simultaneously in the sample during the MT process. The superposition of dynamic mechanisms determines the development of relaxation processes, dissipation of stored internal energy, leveling of internal stress fields relief.

\section{CONCLUSIONS}

A model is proposed for the transformation of the dislocation structure with the presence of inhomogeneous defect structures upon application of an alternating magnetic field. The response of dislocations lying in a field of high internal stresses to a weak harmonic effect is analyzed on the basis of solving an equation of an oscillating stringmodel. The role of the dynamic properties of dislocations in a mechanically unstable state in the development of microplastic processes during magnetic treatment is determined. It is shown that in the region of microplastic deformation several different relaxation mechanisms with their own local relaxation times can act simultaneously. 


\section{REFERENCES}

1. I.M. Neklyudov, Ya.D. Starodubov, V.I. Sokolenko. Vliyaniye magnitny'kh polej na soprotivleniye plasticheskoj deformatsii kristallicheskikh tel // Ukr. fiz. zhyrn. 2005, t. 50, N 8A (in Russian).

2. I.M. Neklyudov, V.M. Azhazha, V.I. Sokolenko, O.V. Mats, V.M. Gorbatenko, V.C. Okovit, M.O. Chernyak, V.M. Netiosov. Sposib magnitnoi obrobky vyrobiv z magnitouporyadkovany'kh metalevy'ch splaviv / Patent na vynakhid N94178. Opubl. 11.04.2011 (in Ukrainian).

3. I.M. Neklyudov, K.A. Yushenko, V.I. Sokolenko, et al. Strukturnaya relaksatsiya i izmeneniye fizikomekhanicheskikh svoistv geterogeny'kh materialov pod dejstviem peremennogo magnitnogo polya // Materialy IV Mezhdunarodnoj konferentsij "Strukturna relaksatsiya u tverdy'kh tilakh”. Ukraina, Vinnitsya, 2012, 29-31 travnya, s. 64-68 (in Ukrainian).

4. N.A. Chernyak, V.I. Sokolenko, A.V. Mats. Vliyaniye magnitnoj obrabotki na magnitnuye svoistva korpusnoj stali 15KH2NMFA // Trudy XX Mezhdunarodnoj konferentsii po fizike radiatsionn'ykh yavlenij $i$ radiatsionnomu materialovedeniyu. Ukraina, Krym, Alushta, 2012, 10-15 sentyabrya, s. 184-185 (in Russian).

5. K.A. Yushenko, A.V. Mats, I.M. Neklyudov, V.I. Sokolenko, N.A. Chernyak. Vliyaniye peremennogo magnitnogo polya na magnitnye svoistva, strukturu i napryazhennoe sostoyaniye svarny'kh soedinenij korpusnoj stali // Avtomaticheskaya svarka. 2017, N 4(763), s. 11-14 (in Russian).

6. V.I. Sokolenko, A.V. Mats, V.I. Karas', et al. Changes in physical-mechanical properties and structure of ferritic-pearlitic steel 15Kh2NMFA caused by severe low-temperature deformation and exposure to alternating magnetic field // Low Temperature Physics. 2015, v. 41, N 4, p. 399-404.

7. I.M. Neklyudov, V.M. Azhazha, V.I. Sokolenko, et al. Izmeneniye deformatsionnoj podatlivosti korpusnoy stali $15 \mathrm{KH} 2 \mathrm{NMFA} \mathrm{v}$ rezul'tate magnitnykh vosdejstviy // Trudy XVIII Mezhdunarodnoj konferentsij po fizike radiatsionn'ykh yavleniy $i$ radiatsionnomu materialovedeniyu. Ukraina, Krym, Alushta, 2008, 8-13 sentyabrya, s. 156-157 (in Russian).

8. I.M. Neklyudov, K.A. Yushenko, V.I. Sokolenko, et al. Vliyaniye oblucheniya i magnitnoj obrabotki na mekhanicheskiye svoystva svarnogo soyedineniya korpusnoy stali 15Kh2NMFA // Mezhdunarodnaya konferentsiya 'Konstruktsionnaya prochnost' materialov $i$ resurs oborudovaniya AES”, Ukraina, Kiev, 02-06 oktyabrya, 2012, s. 151-152 (in Russian).

9. G. Tang, Z. Xu, M. Tang, X. Chen, H. Zhou, A. Lu. Effect of pulsel magnetic treatment on the dislocation substructure of a commercial high strength steel // Mat. Sci. and Eng. 2005, v. A208, p. 108-112.

10. V.I. Karas', V.I. Sokolenko. Nonequilibrium kinetics of the electron-phonon subsystem can give rise to electric- and magnetic-plasticity effects in crystals in alternating electric in/or magnetic fields // PhysicsUspekhi. 2018, v. 188, N 11, p. 1051-1071.

11. A.S. Novick, B.S. Berry. Anelastic Relaxation in Crystalline Solids. Academic Press New York and London, 1972, $470 \mathrm{p}$.

12. A. Granato, K. Luche. Theory of Mechanical Damping One to Dislocations // J. Appl. Phys. 1956, v. 27, p. 583-593.

13. A.V. Granato. Dislocation Inertial Effects in the Plasticity of Superconductors // Phys. Rev. (B). 1971, v. 4, N 7, p. 2196-2201.

Article received 09.12.2021

\section{МИКРОПЛАСТИЧНОСТЬ КОРПУСНОЙ СТАЛИ 15Х2НМФА В НАПРЯЖЕННО- ДЕФОРМИРОВАННОМ СОСТОЯНИИ ПРИ МАГНИТНОЙ ОБРАБОТКЕ}

\section{Н.А. Черняк, В.И. Соколенко}

Ранее было установлено, что обработка предварительно деформированных образцов корпусной стали 15Х2НМФА, сварных соединений этой стали переменным магнитным полем промышленной частоты существенно улучшает комплекс физико-механических свойств, приводит к снижению уровня и выравниванию рельефа полей внутренних напряжений. Целью настоящей работы являлось построение модели отклика системы дислокаций ферромагнетика в напряженно-деформированном состоянии на магнитное воздействие, основанной на микроскопических свойствах дислокаций в механически неустойчивом состоянии.

\section{МІКРОПЛАСТИЧНІСТЬ КОРПУСНОЇ СТАЛІ 15Х2НМФА В НАПРУЖЕНО-ДЕФОРМОВАНОМУ СТАНІ ПРИ МАГНІТНІЙ ОБРОБЦІ}

\section{М.О. Черняк, В.І. Соколенко}

Раніше було встановлено, що обробка попередньо деформованих зразків корпусної сталі 15Х2НМФА, зварних з'єднань цієї сталі змінним магнітним полем промислової частоти суттєво покращує комплекс фізико-механічних властивостей, призводить до зниження рівня та вирівнювання рельєфу полів внутрішніх напруг. Метою цієї роботи була побудова моделі відгуку системи дислокацій феромагнетика в напруженодеформованому стані на магнітний вплив, заснований на мікроскопічних властивостях дислокацій в механічно нестійкому стані. 